\title{
Simulasi Numerik Model Matematika Arus Lalu Lintas Berbasis Fungsi Velositas Underwood
}

\author{
Muh. Isbar Pratama ${ }^{1, a)}$, Dian Firmayasari ${ }^{1, b)}$, Nur Ahniyanti Rasyid ${ }^{1, c)}$, Harianto ${ }^{1, d)}$ \\ ${ }^{1}$ Ilmu Aktuaria, Fakultas Matematika dan Ilmu Pengetahuan Alam, Universitas \\ Muhammadiyah Bulukumba \\ a) muhisbarpratama@umbulukumba.ac.id \\ b) nurahniyantirasyid@umbulukumba.ac.id \\ c)dianfirmayasari@umbulukumba.ac.id \\ d) harianto@umbulukumba.ac.id
}

\begin{abstract}
Abstrak.Model matematika arus lalu lintas pertama kali dikembangkan oleh Lighthill, Whitham dan Richards pada tahun 1956 yang dikenal dengan model (LWR). Dalam model LWR, fungsi kecepatan adalah unsur yang terpenting. Dalam makalah ini digunakan fungsi kecepatan underwood karena memiliki tingkat kesesuaian yang terbaik dibadingkan dengan fungsi kecepatan lainnya. Metode beda hingga implisit digunakan untuk menemukan solusi numerik model LWR dengan model kecepatan Underwood. Konvergensi metode beda hingga implisit dibuktikan dengan menggunakan teorema Ekuivalensi Lax. Simulasi numerik jalan raya satu lajur sepanjang $10 \mathrm{~km}$ dilakukan selama 1 jam menggunakan metode beda hingga implisit berdasarkan data awal dan batas yang dibuat secara artifisial. Simulasi numerik dilakukan dengan dua parameter berbeda. Hasil eksperimen menujukkan bahwa semakin tinggi rata-rata kepadatan kendaraan pada suatu laju mengakibatkan rata-rata kecepatan kendaraan akan berkurang.

Kata kunci: Metode Beda Hingga Implisit, Model LWR, Arus Lalu Lintas, Fungsi Felositas Underwood, Simulasi Numerik.
\end{abstract}

Kata kunci : Abstract. Mathematical traffic flow model was first developed by Lighthill, Whitham and Richards in 1956, known as (LWR) model. In LWR model, velocity function was most important. In this paper, Underwood velocity function was used. Implicit finite difference method used to found the numerical solution of LWR model with Underwood velocity model. Convergence the implicit finite difference method proved using the Lax equivalence theorem. The numerical simulation of $10 \mathrm{~km}$ highway of single lane was performed for 1 hours using the implicit finite difference method based on artificially generated initial and boundary data. Numerical simulation performed with two different parameters. An experimental result for the stability condition of the numerical scheme was also presented. Density, velocity, and fluks for 1 hours was experimental result of numerical simulation.

Keywords: Implicit finite difference method, Lax equivalence theorem, LWR model, Traffic flow, Underwood velocity Function, Numerical simulation.

\section{LATAR BELAKANG}

Kebutuhan akan transportasi dalam beberapa tahun terakhir meningkat secara drastis, hal ini disebabkan oleh meningkatnya pertumbuhan penduduk yang diimbangi dengan pesatnya pertumbuhan perekonomian. Peningkatan kebutuhan transportasi menimbulkan permasalahan 
baru. Salah satu masalah besar yang dihadapi oleh negara-negara berkembang dalam bidang transportasi adalah masalah kepadatan arus lalu lintas.

Fenomena kepadatan arus lalu lintas dapat dianalisis dengan bantuan model matematika. Model matematika tentang arus lalu lintas mengkaji tentang interaksi antara kendaraan, pengemudi dan infrastruktur dengan tujuan memahami dan mengembangkan jaringan jalan yang optimal dengan pergerakan lalu lintas yang efisien dan minim masalah kemacetan lalu lintas. Diantara beberapa jenis pemodelan arus lalu lintas di atas, model makroskopik arus lalu lintas adalah model yang terbaik karena lebih efisien dan mudah diimplementasikan daripada pendekatan model lainnya (Sultana, 2013).

Model arus lalu lintas makroskopik pertama kali dikembangkan pada tahun 1955 oleh James Lighthill, Gerald B. Whitham dan Richard P. yang berhasil merumuskan tentang arus kepadatan jalan kedalam bentuk persamaan diferensial parsial yang dikenal sebagai model LWR. Model ini menggambarkan fenomena lalu lintas yang dihasilkan dari interaksi banyak kendaraan dengan variabel dasar lalu lintas seperti kepadatan, kecepatan dan aliran kendaraan dan dapat diguanakan untuk memprediksi fenomena kepadatan arus lalu lintas kedepannya.Dalam model LWR, Fungsi Velositas ( rata-rata kecepatan yg diukur dalam satuan jarak persatuan waktu.) merupakan elemen yang paling penting dalam menentukan kecocokan model. Pada model LWR konvesional Fungsi Velositas diasumsikan sebagai fungsi linear. Asumsi ini kemudian mendapat banyak bantahan dari beberapa peneliti karena velositas yang linear dalam prakteknya tidak realistis (Sultana, 2013). Beberapa model yang diusulkan oleh beberapa peneliti untuk memodelkan velositas antara lain Fungsi Velositas Greenberg, Fungsi Velositas Underwood, Fungsi Velositas Drake, Fungsi Velositas polinomial, dan Fungsi Velositas Kuadratik. Diantara beberapa model tersebut, Fungsi Velositas Underwood adalah model yang terbaik karena memiliki nilai koefisien determinasi terbesar (Ardekani, 2011).

Tujuan penelitian ini menggambarkan pola pergerakan lalu lintas menggunakan model LWR dengan Fungsi Velositas Underwood yang merupakan fungsi taklinear. Karena model LWR dengan velositas Underwood memiliki bentuk persamaan diferesial parsial taklinear sehingga diperlukan suatu metode numerik untuk menentukan solusinya. Salah satu pendekatan secara numerik dapat dilakukan untuk menentukan solusi model LWR yaitu dengan metode beda hingga (finite difference method), Pada penelitian ini menggunakan metode beda hingga skema implisit.

\section{TUJUAN PENELITIAN}

Tujuan penelitian ini adalah melakukan simulasi numerik untuk menggambarkan dan memprediksi fenoomena arus lalu lintas dengan metode beda hingga implisit (Implicit finite difference method) terhadap model LWR dengan fungsi velositas Underwood.

\section{TINJAUAN PUSTAKA}

\section{Turunan Parsial}

\section{Definisi}

Andaikan bahwa $f$ adalah suatu fungsi dua variabel $x$ dan $y$. jika $y$ di jaga agar tetap konstan, katakanlah $y=y_{0}$, maka $f\left(x, y_{0}\right)$ adalah fungsi satu variabel $x$. Turunannya di $x=x_{0}$ disebut turunan parsial $f$ terhadap $x$ di $\left(x_{0}, y_{0}\right)$ dan dinyatakan oleh $f_{x}\left(x_{0}, y_{0}\right)$. Jadi

$$
f_{x}\left(x_{0}, y_{0}\right)=\lim _{\nabla x \rightarrow 0} \frac{f\left(x_{0}+\Delta x, y_{0}\right)-f\left(x_{0}, y_{0}\right)}{\Delta x}
$$


Dengan cara serupa, turunan parsial f terhadap y di $\left(x_{0}, y_{0}\right)$ dinyatakan oleh $f_{y}\left(x_{0}, y_{0}\right)$ dan diberikan oleh

$$
f_{y}\left(x_{0}, y_{0}\right) \lim _{\nabla y \rightarrow 0} \frac{f\left(x_{0}, y_{0}+\Delta x\right)-f\left(x_{0}, y_{0}\right)}{\Delta y}
$$

Misalkan $f$ suatu fungsi tiga variabel $x, y$, dan $z$. Turunan parsial $f$ terhadap $x$ di $(x, y, z)$ dinyatakan oleh $f(x, y, z)$ dan didefenisikan oleh

$$
f_{x}(x, y, z)=\lim _{\nabla x \rightarrow 0} \frac{f(x+\Delta x, y, z)-f(x, y, z)}{\Delta x}
$$

Turunan parsial terhadap y dan z didefenisikan secara serupa.

(Varberg, dkk, 2007)

\section{Fungsi Velositas}

Fungsi Velositas adalah model yang menggambarkan rata-rata kecepatan yg diukur dalam satuan jarak persatuan waktu. Fungsi Velositas menggambarkan hubungan antara kecepatan dan kepadatan kendaraan. Fungsi Velositas arus lalu lintas pertama kali diperkenalkan oleh Greenshield pada tahun 1939 yang menggambarkan Fungsi Velositas arus lalu lintas sebagai fungsi linear. Seiring dengan berkembangnya ilmu pengetahuan, banyak peneliti yang mengajukan Fungsi Velositas arus lalu lintas.

\section{Fungsi Velositas Greenberg}

Diperkenalkan oleh Greenberg pada tahun 1959, model menggunakan analogi aliran fluida dan data dari Terowongan Lincoln di New York untuk membangun logaritmik hubungan antara kecepatan dan kepadatan, yaitu

$$
V(\rho)=V_{\max }\left(\ln \left(\frac{\rho(x, t)}{\rho_{\max }}\right)\right)
$$

\section{Fungsi Velositas Underwood}

Dikembangkan oleh Underwood pada tahun 1961, model hipotesis hubungan eksponensial antara kepadatan dan kecepatan. Model ini umumnya memiliki lebih baik daripada model Greenshields dan Greenberg (Ardekani, Mostafa, \& Shiva, 2011). Model Underwood diberikan oleh

$$
V(\rho)=V_{\max } \cdot \exp \left(-\frac{\rho(x, t)}{\rho_{\max }}\right)
$$

\section{Fungsi Velositas Underwood dengan ekspansi deret Taylor}

Model Underwood tidak menghasilkan solusi bagi puncak kepadatan ketika kecepatan mendekati nol. Tetapi fungsi eksponensial dapat diperluas dalam serangkaian Taylor untuk memperoleh pendekatan numerik puncak kepadatan.

$$
V(\rho)=V_{\max } \cdot \exp \left(-\frac{\rho(x, t)}{\rho_{\max }}\right)=V_{\max }\left(1-\frac{\rho}{\rho_{\max }}+\frac{\rho^{2}}{2 \rho_{\max }^{2}}-\frac{\rho^{3}}{6 \rho_{\max }^{2}}\right)
$$

\section{Fungsi Velositas Kuadratik}

Model kuadratik dikembangkan oleh Ardekani, dkk pada tahun 2011. Dengan hubungan antara kepadatan dan kecepatan diberikan oleh

$$
V(\rho)=V_{\max }\left(1-\frac{\rho^{2}}{\rho_{\max }}\right)
$$




\section{Koefisien Determinasi $\left(R^{2}\right)$}

Koefisien determinasi $\left(R^{2}\right)$ adalah satu ukuran yang digunakan untuk mengukur pengaruh variabel independen terhadap variansi variabel dependen, dengan $0<R^{2}<1$. Koefisien determinasi sering digunakan sebagai alat untuk menguji kelayakan suatu model. Semakin besar nilai dari $R^{2}$ maka model semakin mendekati kodisi yang sebenarnya.

\section{Perbandingan Fungsi Velositas}

Membandingkan Fungsi Velositas yang paling cocok untuk kondisi aliran bebas hambatan perlu dilakukan sebagai masukan untuk model makroskopis untuk memprediksi kecepatan yang berlaku (Ardekani, dkk, 2011).

(Ardekani, dkk, 2011) membandingkan Fungsi Velositas untuk Southbound loop 12 Freeway di Irving Blvd di Dallas, Texas. Berdasarkan nilai koefisien $R^{2}$ Fungsi Velositas Underwood adalah model terbaik dengan nilai $R^{2}$ sebesar 0.96 yang artinya kemampuan variabel bebas model Underwood dalam menjelaskan varians dari variabel terikatnya sebesar 0.96 .

TABEL 1. Perbandingan nilai $R^{2}$ (Ardekani, dkk, 2011)

\begin{tabular}{lc} 
Fungsi Velositas & $\boldsymbol{R}^{\mathbf{2}}$ \\
GreenShield & 0.86 \\
Greenberg & 0.43 \\
Underwood & $\mathbf{0 . 9 6}$ \\
Drake & 0.94 \\
Polynomial & 0.91 \\
Kuadrat & 0.90 \\
\hline
\end{tabular}

\section{Deret Taylor}

Misalkan $f$ fungsi kontinu pada selang tertutup $[a, b]$ dan $f^{\prime}, f^{\prime \prime}, f^{\prime \prime}, \ldots$ menyatakan turunan pertama, kedua, ketiga, dan seterusnya, yang juga kontinu pada selang tersebut. Misalkan $x_{0} \in[a, b]$, maka untuk nilai $x$ di sekitar $x_{0}$ dengan $x \in[a, b], f(x)$ dapat diperluas (diekspansi ke dalam deret Taylor) sebagaimana persamaan 8 berikut.

$$
f\left(x_{0}\right)+\left(x-x_{0}\right) f^{\prime}\left(x_{0}\right)+\frac{\left(x-x_{0}\right)^{2}}{2 !} f^{\prime \prime}\left(x_{0}\right)+\cdots
$$

Jadi dimisalkan $x-x_{0}=h$, maka $f(x)$ dapat juga ditulis seperti persamaan 9 berikut

$$
f(x)=f\left(x_{0}\right)+\frac{h}{1 !} f^{\prime}\left(x_{0}\right)+\frac{h^{2}}{2 !} f^{\prime \prime}\left(x_{0}\right)+\ldots+\frac{h^{n}}{n !} f^{n}\left(x_{0}\right)+\ldots
$$

\section{Skema Metode beda hingga Implisit}

Pada skema implisit variabel pada waktu $n+1$ dihitung berdasarkan variabel pada waktu $n$ yang sudah diketahui serta variavel pada waktu $n+1$ yang belum diketahui. Sehingga, operator beda hingga yang di gunakan adalah sebagai berikut

$$
\left.\begin{array}{c}
\frac{\partial \rho\left(t^{n}, x_{i}\right)}{\partial t}=\frac{\rho\left(t_{i}^{n+1}\right)-\rho\left(t_{i}^{n}\right)}{\Delta t} \\
\frac{\partial \rho\left(t^{n}, x_{i}\right)}{\partial x}=\frac{\rho\left(t_{i+1}^{n+1}\right)+\rho\left(t_{i-1}^{n+1}\right)}{2 \Delta x}
\end{array}\right\}
$$




\section{Sistem Persamaan Non Linear}

Sistem persamaan nonlinear merupakan kumpulan dari beberapa persamaan nonlinear dengan fungsi tujuannya saja atau bersama dengan fungsi kendala berbentuk nonlinier, yaitu pangkat dari variabelnya lebih dari satu . Ada beberapa fungsi tujuan dalam persamaan nonlinear yang tidak bisa diselesaikan secara analitik, tetapi dapat diselesaikan dengan metode-metode khusus untuk penyelesaian masalah dalam persamaan nonlinier. Untuk menyelesaikan permasalahan persamaan nonlinier terdapat banyak metode dan algoritma yang bisa digunakan, tetapi setiap metode dan algoritma yang ada mempunyai kelebihan dan kekurangan masing-masing. Salah satunya metode numerik digunakan untuk menyelesaikan persoalan dimana perhitungan secara analitik tidak dapat digunakan. Ada banyak macam metode numerik untuk menyelesaikan sistem persamaan linear maupun sistem persamaan nonlinear diantaranya metode Newton-Raphson dan metode Jacobian.

\section{Metode Iterasi Newton-Raphson}

Metode Newton-Raphson (umumnya disebut dengan metode Newton) merupakan metode penyelesaian persamaan non-linear yang sering digunakan diantara metode lainnnya, karena metode ini memberikan konvergensi yang lebih cepat dibandingkan dengan metode lainnya. Metode Newton sering konvergen dengan cepat, terutama bila iterasi dimulai "cukup dekat" dengan akar yang diinginkan. Namun bila iterasi dimulai jauh dari akar yang dicari, metode ini dapat meleset tanpa peringatan. Implementasi metode ini biasanya mendeteksi dan mengatasi kegagalan konvergensi.

Metode Newton Raphson merupakan metode yang paling dikenal untuk mencari hampiran terhadap akar fungsi riil dan dapat memecahkan persamaan $f(x)=0$, dengan $f$ diasumsikan mempunyai turunan kontinu f'. Metode ini menggunakan suatu garis lurus sebagai hampiran fungsi. Garis tersebut adalah garis singgung pada kurva. Dengan menggunakan suatu nilai awal xo dan ditetapkan xi adalah titik potong sumbu x dengan garis singgung pada kurva $f$ dititik xo.maka Dalam setiap iterasi akan terbentuk xi secara berulang-ulang hingga manghasilkan nilai $x$ yang membuat $f(x)=0$.

\section{METODE PENELITIAN}

1. Merekonstruksi model LWR dengan mensubtitusikan Fungsi Velositas Underwood.

2. Menyelesaikan solusi analitik model LWR hasil rekonstruksi dengan metode karakteristik.

3. Melakukan diskretisasi untuk model LWR hasil rekonstruksi dengan diskritisasi beda hingga implisit untuk diskritisasi ruang dan waktu.

4. Memeriksa kekonvergenan skema numerik metode beda hingga implisit untuk model LWR hasi rekonstruksi.

5. Melakukan simulasi numerik untuk menunjukkan akurasi dari metode diskretisasi beda hingga implisit.

\section{HASIL DAN PEMBAHASAN}

\section{Model LWR}

Model LWR yang dikembangkan oleh Lighthill dan William (1955), Richard (1956) bertujuan untuk memodelkan kepadatan lalu lintas secara makroskopik. Pada model ini, kondisi lalu lintas dianalogikan sebagai aliran fluida dengan mengasumsikan kendaraan sebagai partikel yang berada pada aliran tersebut. Lebih jauh lagi, pola arus lalu lintas dimodelkan melalui metode 
dinamika fluida. Melalui hukum konservasi massa, diperoleh bahwa model LWR dirumuskan secara matematis oleh persamaan diferensial parsial hiperbolik sebagai berikut:

$$
\frac{\partial \rho(x, t)}{\partial t}+\frac{\partial q(\rho)}{\partial x}=0
$$

dengan $\rho(x, t)$ merepresentasikan kepadatan kendaraan (jumlah kendaraan per satuan jarak) lalu lintas pada suatu titik $x$ dan waktu $t$, sedangkan $q(\rho)$ merepresentasikan fluks (jumlah kendaraan per satuan waktu) lalu lintas pada suatu titik $x$ dan waktu $t$ tertentu.

Fluks lalu lintas merupakan fungsi yang diberikan oleh

$$
q(\rho)=\rho . V(\rho)
$$

dengan $V(\rho)$ adalah Fungsi Velositas (rata-rata kecepatan yg diukur dalam satuan jarak persatuan waktu).

\section{Fungsi Velositas Underwood}

Dikembangkan oleh Underwood pada tahun 1961, model hipotesis hubungan eksponensial antara kepadatan dan kecepatan. Model ini umumnya memiliki lebih baik daripada model Greenshields dan Greenberg (Ardekani, dkk, 2011). Model Underwood diberikan oleh

$$
V(\rho)=V_{\max } \cdot \exp \left(-\frac{\rho(x, t)}{\rho_{\max }}\right)
$$

dengan $V_{\text {max }}$ adalah kecepatan maksimum yang dapat dicapai kendaraan pada kepadatan tertentu dan $\rho_{\max }$ adalah kepadatan maksimum kendaraan pada suatu ruas jalan.

\section{Model LWR dengan velositas Underwood}

Persamaan (11) direkonsruksi dengan mensubtusikan Fungsi Velositas underwood pada persamaan (13).

$$
\frac{\partial \rho(x, t)}{\partial t}+\frac{\partial}{\partial x}\left(\rho(x, t) \cdot V_{\max } \cdot \exp \left(-\frac{\rho(x, t)}{\rho_{\max }}\right)\right)=0
$$

dengan asumsi bahwa kepadatan lalu lintas pada saat awal pengamatan yaitu pada saat $t=0$

$$
\rho(x, 0)=\rho_{0}(x)
$$

Sehingga model LWR dengan masalah nilai awal yang diberikan dapat dituliskan sebagai:

$$
\left.\begin{array}{c}
\frac{\partial \rho(x, t)}{\partial t}+\frac{\partial}{\partial x}\left(\rho(x, t) \cdot V_{\text {max }} . \exp \left(-\frac{\rho(x, t)}{\rho_{\max }}\right)\right)=0 \\
\rho(x, 0)=\rho_{0}(x)
\end{array}\right\}
$$

\section{Solusi Analitik dengan Metode Karakteristik}

Pada bagian ini, masalah nilai awal persamaan (13) akan diselesaikan dengan metode karakteristik.

dengan

$$
\begin{gathered}
\frac{\partial q(x, t)}{\partial x}+\frac{\partial \rho(x, t)}{\partial t}=0 \\
\frac{\partial(\rho . V(\rho))}{\partial x}+\frac{\partial \rho(x, t)}{\partial t}=0
\end{gathered}
$$

$$
\begin{aligned}
\frac{\partial(\rho \cdot V(\rho))}{\partial x} & =V(\rho) \cdot \frac{d \rho}{d x}+\rho \cdot \frac{\partial(V(\rho))}{\partial x} \\
& =V(\rho) \cdot \frac{d \rho}{d x}+\rho \cdot \frac{d V}{d \rho} \frac{\partial \rho}{\partial x} \\
& =\left(V(\rho)+\rho \cdot \frac{d V}{d \rho}\right) \frac{\partial \rho}{\partial x}
\end{aligned}
$$

Dengan mensubtitusikan (18) ke (17) diperoleh 
dengan

$$
\left(V(\rho)+\rho \cdot \frac{d V}{d \rho}\right) \frac{\partial \rho}{\partial x}+\frac{\partial \rho(x, t)}{\partial t}=0
$$

Di mana

$$
V(\rho)=V_{\text {maks }} \cdot \exp \left(-\frac{\rho}{\rho_{\text {maks }}}\right)
$$

$$
\begin{aligned}
\left(V(\rho)+\rho \cdot \frac{d V}{d \rho}\right) & =V_{\text {max }} \cdot \exp \left(-\frac{\rho}{\rho_{\text {max }}}\right)+\rho\left(-\frac{V_{\text {maks }}}{\rho_{\text {maks }}} \cdot \exp \left(-\frac{\rho}{\rho_{\text {maks }}}\right)\right) \\
& =\left(V_{\text {maks }}-\frac{\rho \cdot V_{\text {maks }}}{\rho_{\text {maks }}}\right) \cdot \exp \left(-\frac{\rho}{\rho_{\text {maks }}}\right)
\end{aligned}
$$

Dengan demikian persamaan (17) dapat di tulis dalam bentuk

$$
\frac{\partial \rho(x, t)}{\partial t}+\frac{\partial \rho}{\partial x}\left(\left(V_{\text {maks }}-\frac{\rho \cdot V_{\text {maks }}}{\rho_{\text {maks }}}\right) \cdot \exp \left(-\frac{\rho}{\rho_{\text {maks }}}\right)\right)=0
$$

Selanjutnya persamaan (22) akan diselesaikan dengan metode karakteristik., Total derivatif $\rho(x, t)$ adalah

Dengan demikian

$$
\begin{gathered}
\frac{d \rho}{d t}=\frac{\partial \rho}{\partial x}+\frac{d x}{d t} \frac{\partial \rho}{\partial x}=0 \\
\frac{d \rho}{d t}=0
\end{gathered}
$$

$$
\frac{d x}{d t}=\left(\left(V_{\text {maks }}-\frac{\rho \cdot V_{\text {maks }}}{\rho_{\text {maks }}}\right) \cdot \exp \left(-\frac{\rho}{\rho_{\text {maks }}}\right)\right)
$$

Sehingga persamaan garis karakteristiknya adalah

$$
x(t)-\left(\left(V_{\text {maks }}-\frac{\rho \cdot V_{\text {maks }}}{\rho_{\text {maks }}}\right) \cdot \exp \left(-\frac{\rho}{\rho_{\text {maks }}}\right)\right) \cdot t=c_{1}
$$

Solusi dari persamaan (4.12) sepanjang garis karakteristik (4.15) adalah

Untuk sembarang fungsi $f$.

$$
\rho(x, t)=f\left(x(t)-\left(\left(V_{\text {maks }}-\frac{\rho \cdot V_{\text {maks }}}{\rho_{\text {maks }}}\right) \cdot \exp \left(-\frac{\rho}{\rho_{\text {maks }}}\right)\right) \cdot t\right)
$$

\section{Diskretisasi}

Dengan menggunakan diskretisasi skema Implisit terhadap ruang dan waktu model LWR (14) diaproksimasi mengikuti bentuk metode beda hingga implisit menggunakan operator (10) beda hingga implisit menjadi seperti berikut:

$$
\frac{\rho_{i}^{n+1}-\rho_{i}^{n}}{\Delta t}+W \frac{\rho_{i+1}^{n+1}+\rho_{i-1}^{n+1}}{2 \Delta x}=0
$$

dengan

selanjutnya diperoleh:

$$
W=\left(V_{m a k s}-\frac{\rho_{i}^{n} \cdot V_{m a k s}}{\rho_{\text {maks }}}\right) \cdot \exp \left(-\frac{\rho_{i}^{n}}{\rho_{\text {maks }}}\right)
$$

$$
\frac{W}{2 \Delta x} \rho_{i+1}^{n+1}+\frac{1}{\Delta t} \rho_{i}^{n+1}+\frac{W}{2 \Delta x} \rho_{i-1}^{n+1}=\frac{1}{\Delta t} \rho_{i}^{n}
$$

Untuk penyederhanaan, persamaan (29) dapat dituliskan menjadi bentuk berikut

$$
\alpha_{i}^{n+1} \rho_{i+1}^{n+1}+\beta_{i}^{n+1} \rho_{i}^{n+1}+\gamma_{i}^{n+1} \rho_{i-1}^{n+1}=\frac{1}{\Delta \mathrm{t}} \rho_{i}^{n},
$$

untuk $i=1, \ldots, M-1$ dan $n=1, \ldots, N-1$, di mana:

$$
\left.\begin{array}{c}
\alpha_{i}^{n+1}=\frac{W}{2 \Delta x} \\
\beta_{i}^{n+1}=\frac{1}{\Delta t} \\
\gamma_{i}^{n+1}=\frac{W}{2 \Delta x}
\end{array}\right\}
$$


Didefinisikan syarat awal dan syarat batas untuk persamaan (27) adalah sebagai berikut

$$
\rho_{i}^{0}=\rho\left(\mathrm{X}_{0}\right) \quad \rho_{0}^{n}=\rho\left(t_{a}\right) \quad \rho_{M}^{n}=\rho\left(t_{b}\right) \quad \text { (4.22) }
$$

untuk $i=1,2, \ldots, M-1$ dan $n=1, \ldots, N$, sehingga persamaan (4.20) dapat dituliskan menjadi bentuk matriks berikut

$$
A^{n+1}\left(U^{n+1}\right) \widehat{U}^{n+1}=\frac{1}{\Delta \tau_{n}} \widehat{U}^{n}+B^{n+1},
$$

untuk $n=1, \ldots, N-1$, di mana

$$
\begin{gathered}
A^{n+1}\left(U^{n+1}\right)=\left[\begin{array}{ccccccc}
\beta_{1}^{n+1} & \gamma_{1}^{n+1} & 0 & \cdots & 0 & 0 & 0 \\
\alpha_{2}^{n+1} & \beta_{2}^{n+1} & \gamma_{2}^{n+1} & \cdots & 0 & 0 & 0 \\
0 & \alpha_{3}^{n+1} & \beta_{3}^{n+1} & \cdots & 0 & 0 & 0 \\
\vdots & \vdots & \vdots & \ddots & \vdots & \vdots & \vdots \\
0 & 0 & 0 & \cdots & \beta_{M-3}^{n+1} & \gamma_{M-3}^{n+1} & 0 \\
0 & 0 & 0 & \cdots & \alpha_{M-2}^{n+1} & \beta_{M-2}^{n+1} & \gamma_{M-2}^{n+1} \\
0 & 0 & 0 & \cdots & 0 & \alpha_{M-1}^{n+1} & \beta_{M-1}^{n+1}
\end{array}\right] \\
\widehat{U}^{k}=\left(U_{1}^{k}, U_{2}^{k}, \ldots, U_{M-1}^{k}\right)^{\prime} \text { untuk } k=n, n+1 \\
B^{n+1}=\left(-\alpha_{1}^{n+1} U_{0}^{n+1}, 0, \ldots, 0,-\gamma_{M-1}^{n+1} U_{N}^{n+1}\right)^{\prime}
\end{gathered}
$$

\section{Kekonvergenan dari Skema Numerik}

Teorema Ekuivalensi Lax

Untuk sebuah persamaan diferensial dan masalah nilai awal yang well-possed, jika suatu persamaan beda konsisten dan stabil, maka persamaan beda tersebut konvergen.

\section{Kestabilan}

Kestabilan skema diskritisasi (27) dianalisis menggunakan analisis kestabilan Von Neumann.

Suatu skema diskritisasi metode beda hingga dikatakan stabil jika $\rho_{i}^{n}=K^{n} e^{a i}, \forall a \in \mathbb{R}$, memenuhi $|K| \leq 1$ untuk ruang $i$ dan waktu $n$.

\section{Bukti:}

Persamaan (29) dapat dituliskan sebagai berikut:

$$
M \rho_{i+1}^{n+1}+\rho_{i}^{n+1}+M \rho_{i-1}^{n+1}=\rho_{i}^{n}
$$

untuk $i=1, \ldots, M-1$ dan $n=1, \ldots ., N-1$, dengan

$$
M=\frac{W \Delta t}{2 \Delta x}
$$

dengan mensubitusikan $\rho_{i}^{n}=K^{n} e^{a i}, \forall a \in \mathbb{R}$ maka persamaan (34) dapat dituliskan sebagai berikut:

$$
M K^{n+1} e^{a(i+1)}+K^{n+1} e^{a i}+M K^{n+1} e^{a(i-1)}=K^{n} e^{a i}
$$

dengan membagi kedua ruas dengan $K^{n+1} e^{a i}$ maka persamaan (36) menjadi

$$
\begin{gathered}
M e^{a}+1+M e^{-a}=K^{-1} \\
K=\frac{1}{1+M\left(e^{a}+e^{-a}\right)}
\end{gathered}
$$

Selanjutnya akan dibuktikan $1+M\left(e^{a}+e^{-a}\right) \geq 1$.

$$
\begin{gathered}
M=\left(V_{\text {maks }}-\frac{\rho_{i}^{n} \cdot V_{\text {maks }}}{\rho_{\text {maks }}}\right) \cdot \exp \left(-\frac{\rho_{i}^{n}}{\rho_{\text {maks }}}\right) \frac{\Delta t}{2 \Delta x} \\
\exp \left(-\frac{\rho_{i}^{n}}{\rho_{\text {maks }}}\right)>0, \frac{\Delta t}{2 \Delta x}>0 \text {, dan }\left(e^{j a}+e^{-j a}\right)>0, \forall a \in \mathbb{R} \text {. Karena } \rho_{i}^{n}<\rho_{\text {maks }}, \\
\text { maka }\left(V_{\text {maks }}-\frac{\rho_{i}^{n} \cdot V_{\text {maks }}}{\rho_{\text {maks }}}\right)>0 \text {. Sehingga } 1+M\left(e^{a}+e^{-a}\right) \geq 1 .
\end{gathered}
$$


Selanjutnya

$$
K=\frac{1}{1+M\left(e^{a}+e^{-a}\right)} \leq 1
$$

\section{Kekonsistenan}

Teorema ekuivalensi Lax menyatakan bahwa metode beda hingga konsisten untuk masalah nilai awal yang diberikan (Strikwerda, 1989).

\section{Teorema Kekonvergenan}

Sesuai dengan teorema ekuvalensi Lax Untuk sebuah persamaan diferensial dan masalah nilai awal yang well-possed, jika suatu persamaan beda konsisten dan stabil, maka persamaan beda tersebut konvergen.

\section{Simulasi Numerik}

Pada bagian ini akan diberikan beberapa contoh kasus untuk disimulasikan. Simulasi ini dilakukan untuk mengetahui kecenderungan perubahan arus lalu lintas jika data diubah-ubah. Simulasi ini menggunakan software MATLAB.

Model arus lalu lintas (4.4) disimulasikan menggunakan kepadatan awal jalan $\rho(x, 0)$ berupa grafik yang ditunjukkan pada gambar 1 . Asumsikan kepadatan jalan pada jarak $0 \mathrm{~km}, \rho(0, t)$ adalah konstan sebesar 21 unit (Khabir, dkk, 2011).

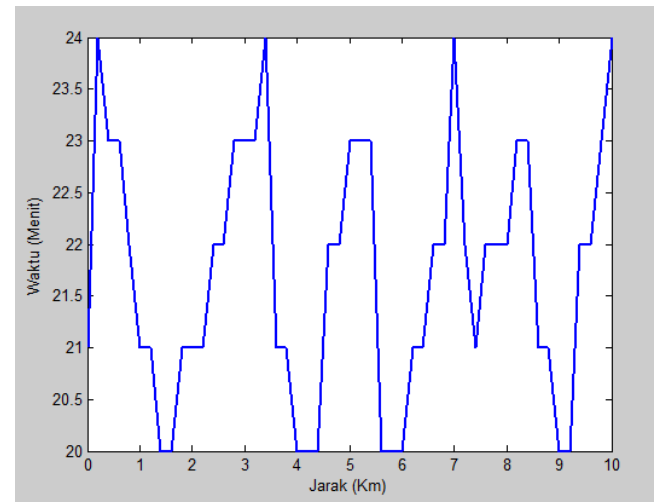

a) Kasus 1

GAMBAR 1. Kepadatan arus lalu lintas pada $T=0$.

Pada kasus ini kepadatan jalan di hitung menggunakan parameter $\rho_{\max }=250, V_{\max }=$ $65 \frac{\mathrm{Km}}{\mathrm{jam}}, \Delta x=0.200, \Delta t=0.0667$ yang diamati selama $T=6$ menit.

Berikut ini gambar kurva kepadatan dan kecepatan lalu lintas berdasarkan parameter yang telah diberikan. 


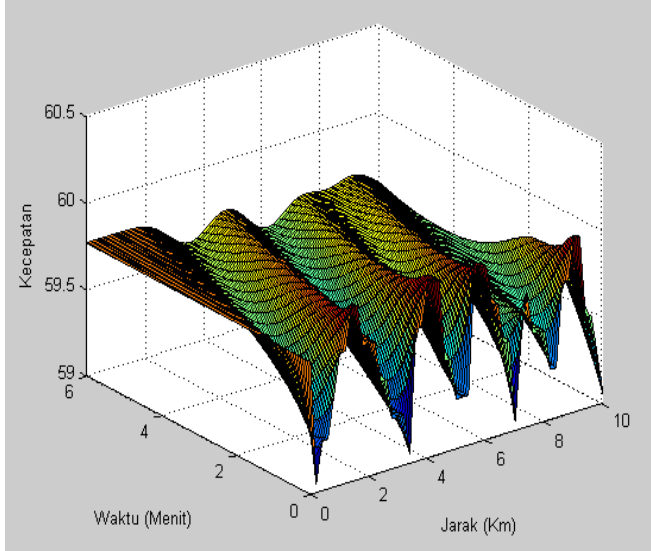

(a)

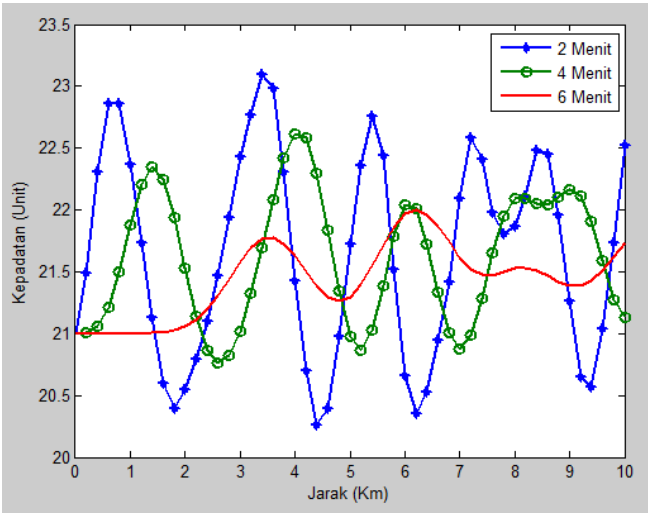

(c)

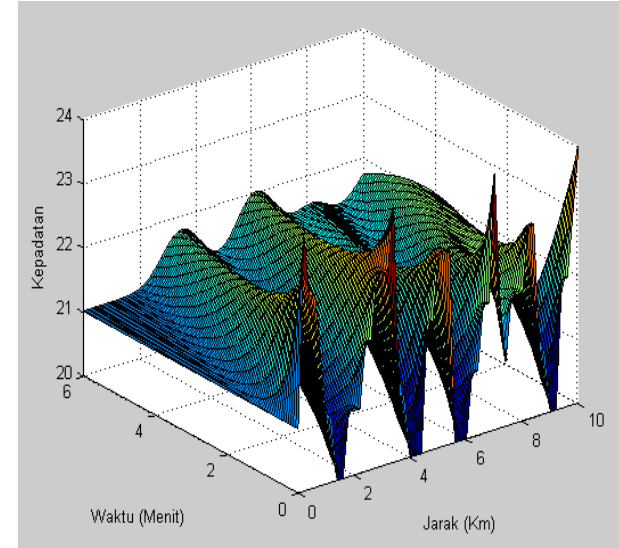

(b)

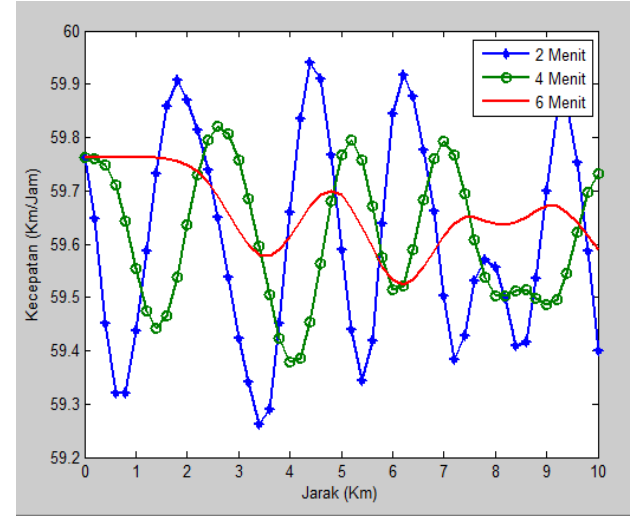

(d)

GAMBAR 2. (a) Profil kepadatan lalu lintas, (b) Profil kecepatan lalu lintas, (c) Grafik kepadatan lalu lintas pada $\mathrm{T}=2$ menit, 4 menit dan 6 menit, (d) Grafik kecepatan lalu lintas pada $\mathrm{T}=2$ menit, 4 menit dan 6 menit.

b) Kasus 2

Pada kasus ini kepadatan jalan di hitung menggunakan parameter kepadatan maksimum kendaraan $V_{\text {max }}=30 \frac{\mathrm{Km}}{\mathrm{jam}}$, parameter lainnya sama dengan kasus 1 .

Berikut ini grafik perubahan kepadatan dan kecepatan lalu lintas pada $T=2$ menit, $T=$ 4 menit, $T=6$ menit.

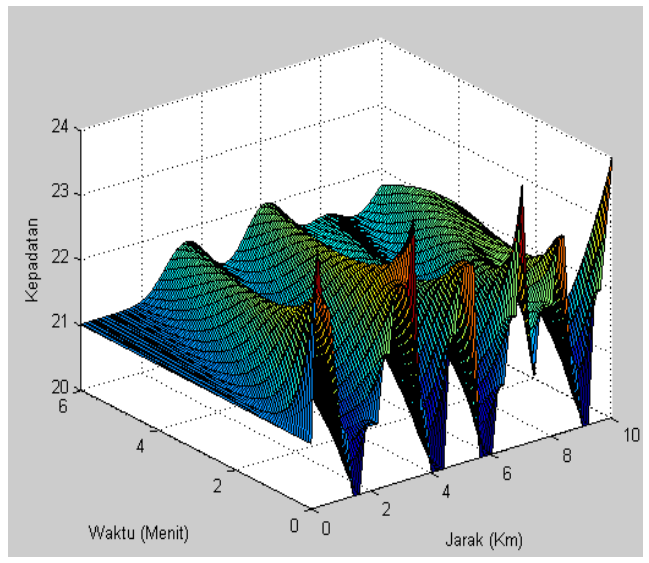

(a)

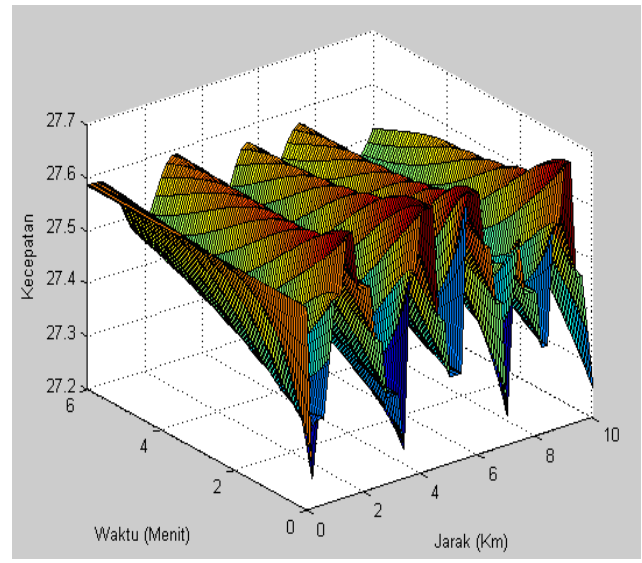

(b) 


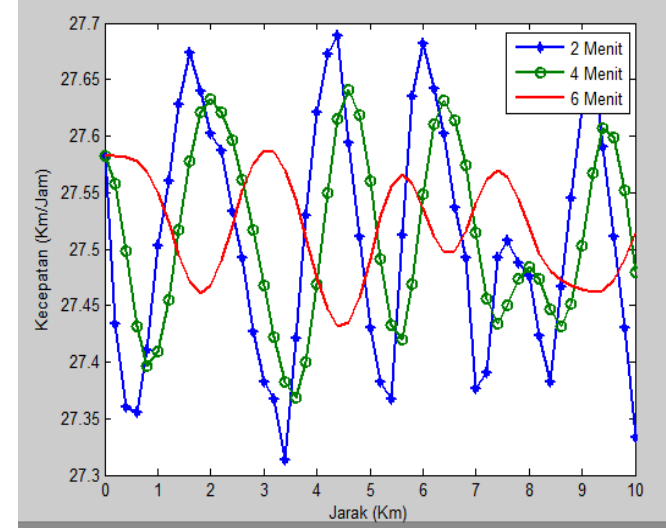

(c)

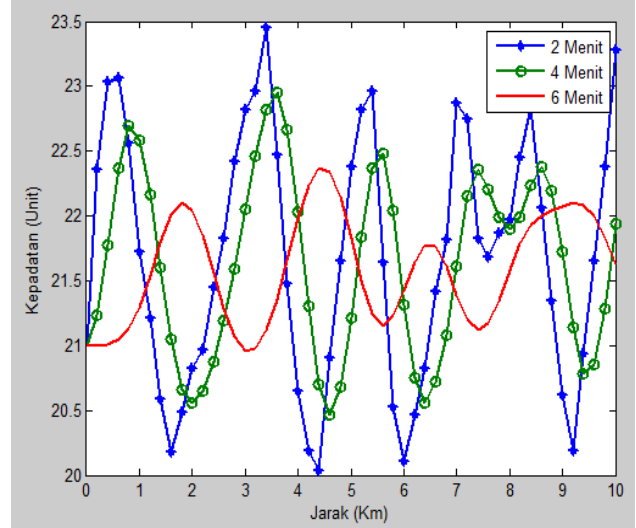

(d)

GAMBAR 3. (a) Profil kepadatan lalu lintas, (b) Profil kecepatan lalu lintas (c) Grafik kepadatan lalu lintas pada $\mathrm{T}=2$ menit, 4 menit dan 6 menit, (d) Grafik kecepatan lalu lintas pada $\mathrm{T}=2$ menit, 4 menit dan 6 menit.

Berdasarkan gambar 2a dan gambar 2b dapat dilihat bahwa seiring dengan bertambahnya waktu dan jarak, maka nilai kepadatan dan kecepatan lalu lintas semakin tidak fluktuatif atau dengan kata lain semakin homogen. Perubahan kepadatan dan kecepatan lalu lintas dapat dilihat lebih detail pada gambar $2 \mathrm{c}$ dan $2 \mathrm{~d}$.

Berdasarkan gambar $2 \mathrm{c}$ dan $2 \mathrm{~d}$ terlihat bahwa seiring berjalannya waktu kepadatan kendaraan akan terurai dengan sendirinya, hal ini disebabkan karena kita mengasumsikan kepadatan jalan pada titik $0 \mathrm{~km}$ adalah konstan. Pada gambar 2c dan 2d juga dapat dilihat hubungan timbal balik antara kepadatan dan kecepatan arus lalu lintas. Semakin besar nilai kepadatan lalu lintas, maka kecepatan arus lalu lintas semakin kecil

Gambar 3a dan 3b menggambarkan kepadatan dan kecepatan lalu lintas bila parameter kepadatan maksimum dikurangi menjadi $30 \frac{\mathrm{Km}}{\mathrm{jam}}$. Dapat dilihat bahwa kepadatan kendaraan akan terurai lebih lambat bila dibandingkan dengan gambar $2 \mathrm{c}$ dan $2 \mathrm{~d}$.

Kepadatan awal memberikan pengaruh yang besar terhadap perubahan kepadatan dan kecepatan lalu lintas di setiap titik.

\section{KESIMPULAN DAN SARAN}

\section{Kesimpulan}

Pada penelitian ini kepadatan lalu lintas dimodelkan oleh model LWR berbasis Fungsi Velositas Underwood dengan syarat awal dan syarat batas diketahui. Solusi dari masalah nilai awal dan batas tersebut dapat memberikan gambaran mengenai kepadatan dan kecepatan lalu lintas pada sebuah ruas jalan dengan kondisi tertentu.

Solusi dari model LWR diperoleh secara analitik menggunakan metode karakteristik dan secara numerik menggunakan metode beda hingga skema implisit dan telah terbukti stabil dan konsisten. Berdasarkan Simulasi numerik diperoleh kecenderungan perubahan arus lalu lintas jika data diubah-ubah.

\section{Saran}

Penelitian model LWR berbasis Fungsi Velositas underwood ini dapat dilanjutkan dengan mempertimbangkan arus masuk atau keluar dipertengahan ruas jalan. 


\section{DAFTAR PUSTAKA}

Ardekani, S.A., Mostafa,G., Shiva, M. (2011). Macroscopic Speed-Flow Models For Characterization Of Freeway And Managed Lanes. Publicat de Universitatea Tehnică.

Kabir,M.H., Gani,M.O., Andallah , L.S. (2010). Numerical simulation of a mathematical traffic flow model based on a nonlinear velocity-density function. Journal of Bangladesh Academy of Sciences, 34. 15-22.

Kiselev, A.B., Kokoreva, A.V., Nikitin,V.E., \& Smirnov,N.N. (2004). Mathematical modelling of traffic flows on controlled roads. Journal of Applied Mathematics and Mechanics, 68. 933-939.

Lighthil, M.J., Witham, G.B. (1955). On Kinematic Waves: I: Flow Movement in Long Rivers, II: A Theory of Traffic Flow on Long Crowded Roads. - In: Proceedings of the Royal Society: A229, London.

Mazare, P.E., Claudel, C.G., Bayen, A.M. (2005). Analytical and grid-free solutions to the Lighthill-Whitham-Richards traffic flow model. Journal of Applied Mathematics and Mechanics, 23. 645-653.

Richard, P.I. (1956). Shock Waves on the Highway. - Operations Research, 4. 42-57.

Stoilova, V., Nikolov, E., Nikolova,N. (2013). Analytical Deriving of Second Order Model of Payne from First Order Lighthil Whitham-Richards Model. Cybernetics And Information Technologies, 13(4).

Strikwerda, J.C. (1989). Finite difference scheme and partial differential Equation (first edition). London (GB): Chapman \& Hall

Sultana, N., Parvin, M., Sarker, R., Andallah, L.S. (2013). Simulaion of traffic flow model with traffic controller boundary. International Journal of Science and Engeenering, 5(1).

Thomas, Tutert. (2013). An empirical model for trip distribution of commuters in the netherlands: transferability in time and space reconsidered. Journal of transport geography, 26. 158-165. 